\title{
The Effect of Blended Learning on Private School Students' Achievement in English and Their Attitudes Towards It
}

\author{
Zeinab Fakhir ${ }^{1} \&$ Majid Abdulatif Ibrahim ${ }^{1}$ \\ ${ }^{1}$ Dept. of English, Faculty of Arts \& Sciences, Middle East University, Amman, Jordan \\ Correspondence: Majid Abdulatif Ibrahim, Dept. of English, Faculty of Arts \& Sciences, Middle East University, \\ Amman, Jordan.
}

Received: December 28, 2017 Accepted: February 19, 2018 Online Published: May 14, 2018

doi:10.5539/ells.v8n2p39 URL: https://doi.org/10.5539/ells.v8n2p39

\begin{abstract}
This study aims at exploring the effect of using blended learning on the achievement of the sixth-grade students in English. The students are of two private primary schools in Amman/Jordan: Alrai School and Alsabelah School. It also scrutinizes their attitudes towards such a type of learning. The study attempts to answer the following questions: (i) What is the effect of using blended learning on the achievement of sixth-grade students in English? (ii) What is the effect fulfilled by blended learning on their attitudes towards such a type of a learning strategy? To reach the goals of the study, the researchers apply quasi-experimental method in which an achievement test is constructed and a questionnaire is prepared in order to measure both students' ability concerning blended learning and their attitudes towards it as well. The study sample consists of 50 female students. It is distributed into two groups (each has 25 female students). The first group is the experimental group taught by using blended learning. The second one is the control group taught by the traditional method. Data is analyzed via adopting (SPSS) and the covariance analysis where (ANCOVA) is applied. The results show that there are statistically significant differences at the level of $(\mathrm{a} \leq 0.05)$ between the means of the results of the two groups on the achievement test, and the difference is in favor of the experimental group.
\end{abstract}

Keywords: blending learning, e-learning, traditional learning, achievement, private school students, students' attitudes

\section{Introduction}

Technology is no longer a luxury in any learning setting. It proves to be a vital part of effective learning. Let's get back few decades ago when teachers were not able to accompany only a few limited resources into their classes. How was that situation? It was a grueling process for a teacher to get the needed resources into his class. Limiting the use of technology only to presentations creates some sort of confusion in relation to its feasibility in improving learning. Teachers need to think of technology as a tool that enables them and their students to reach resources easily and effectively. They can access libraries, hold conferences, watch educational movies, conduct virtual experiments, communicate with experts, record lessons, plan their work, made virtual field trips and many other activities. Some of these activities require weeks of planning and lots of effort within the traditional learning setting.

For this reason, we find many teachers skipping such activities, though they are very useful for their learners due to the time shortage and resources limitations. However, these activities, from the angle of the blended learning strategy, become easier to plan and implement. For example, a visit to the public library can take a full day within the traditional learning strategy; however, students can virtually access the public library records and research for the books and resources they need while being seated in their classrooms or even their bedrooms.

Although technology provides a wide variety of educational solutions and serves effective learning, many are still skeptic of its practicality in the educational environment. Technology forms a distraction and needs a lot of skill to master. In addition, many are afraid of the inconveniences that may occur at any time and may disrupt the class procedures. All of this can be true, but they are so few compared to the advantages that learners and teachers can get.

Blended learning allows learners to visualize, listen, feel, and interact with the learning material. It moves them from theory into practice. They can gain deeper an understanding of all the abstractions they get through. They can 
learn according to their pace, which creates the opportunity for more individualized education. Good achievers can expand their learning and can learn things that are not within the school syllabus. However, the slow achievers can repeat and revise notes and get feedback from their teachers to overcome problems and challenges they face.

Blended learning cannot be introduced as the flawless strategy that can solve all the problems of educational practices. Nevertheless, it proves to be far better than the traditional strategies. Its negative aspects are far less than its positive ones. Educationalists should adopt serious steps for applying technology in their classes and learning environments as it forms the link between the students' inner world and the outside world. Technology gives learners the chance to experience the real world gradually and smoothly.

\subsection{Objectives of the Study}

The study aims at:

1). Detecting the effect of using blended learning on the achievement of sixth-grade students in English enrolling in private primary schools of Amman/Jordan.

2). Scrutinizing their attitudes towards adopting blended learning in teaching English courses.

\subsection{Questions of the Study}

The study is an attempt to answer the following two questions:

1). What is the effect of using blended learning on the achievement of sixth-grade students in English?

2). What is the effect of employing blended learning on their attitudes towards teaching English courses in general?

\subsection{Some Theoretical Manifestations}

Blended learning, hybrid learning, integrated learning, multi-method learning, or mixed method learning all refer to the same concept and strategy of learning in which learning takes place by using two different styles of interaction. Graham (2006) defines blended learning as the conjunction of direct learning settings where students and teachers meet in the same place, basically classroom, to learn with the settings that are based on communication technology, as they can communicate distantly.

On the other hand, Thorne (2003) states that blended learning is an educational model which can integrate e-learning with all of its improvements and enhancements of new technological developments with traditional learning to support interaction in the classroom.

Moreover, Driscoll (2002) identifies four different ways in which blended learning can take place: Firstly, a combination of modes of web-based technology; secondly, the combination of various pedagogical approaches; thirdly, the combination of an instructional technology with face-to-face instruction; and fourthly, the mixture of instructional technology with actual job tasks.

Some researchers and writers agree with Driscoll and define blended learning according to his first concept which is chiefly based on of having that combination of modes of web-based technology. Moreover, he emphasizes that blended learning means different things to different people and illustrates its widely undiscovered potential and power.

Graham (2006) disagrees with Driscoll as they argue that the first and second definitions above suffer from the problem of being too broad, because they apparently include all systems and equipment of virtual learning.

The term "blended learning" is also described by Morgan (2002) as a strategy adopted to combine the best aspects of online learning and face to face learning. Bersin \& Associates (2003) see that:

Blended learning in order to be more effective should take in consideration all educational media that is available inside the classroom, training on the network, the already decisions placed, the available videos, simulations in addition to other means such as telephone communications. (p. 254)

Smythe (2011) refers to blended learning as a practical framework that comprises a variety of operative methods of learning and teaching. It supports the use of computer technologies to facilitate learning and make use of various approaches to motivate students for more engagement.

In fact, blended learning is viewed as a teaching method which blends the use of technology in the learning environment with the traditional learning setting in an attempt to maximize learning to serve the purpose of shifting the setting from a teacher-centered class into a student-centered class. This definitely helps in improving the quality of teaching-learning process by means of enhancing its outputs, creating new potentials for self- learning as well as lifelong learning.

Blended learning can be represented in a wide variety of implementation models. Valiathan (2002) categorizes 
blended learning into three models in terms of their drive. In the first place, there is the skill-driven learning model which integrates self-directed learning with teacher's support to improve his knowledge and skills in a certain topic. Next, there is attitude-driven learning model which blends various activities and delivery media to develop certain behaviors. Thirdly, there is the competency-driven learning model that blends action support tools with knowledge resources to develop classroom competencies.

On the same footing, Wilson (2013) classifies blended learning into six models in terms of their delivery. The face to face model, allowing teachers to use technology in classroom in particular situations, is suggested to help those students who have capabilities more than their peers to allow them advance ahead and achieve better learning or to help students who face problems with keeping up with the class pace mainly in language learning classes. Apart from the first model, the rotation model requires students to rotate their learning setting from traditional classroom to a lab according to pre-scheduled sessions. It gives students the chance to learn via online resources and figure out how things work. On the other hand, the flex model, which involves full online learning under the supervision and help of a teacher, is introduced for those students who have behavioral, academic, and social challenges. It provides them with a safer learning environment. Similarly, online lab model involves students to go to online lab in order to take some courses, not because of the challenges that have been already mentioned with the flex model, but because of the limitations a school has such as not offering a certain course. In addition to having courses that are not offered by the school, students can work in a pace that suits them. The self-blend model, which involves self-selected subjects to learn, meets the needs of high school students who look for extra courses to help them in university admission or getting a job. The last model is the online model where students of limited time can meet their teachers via online and selectively come to have face-to face classes or attend meetings. This model offers a high level of flexibility.

\subsection{Hypotheses of the Study}

The present study is chiefly based on testing the following two null hypotheses:

1). There are no statistically significant differences concerning the achievement of the English students attributed to the teaching method (blended learning and traditional method).

2). There are no statistically significant differences in relation to the attitudes of English students towards the teaching method (blended learning and traditional method).

\section{Methodology of the Study}

\subsection{The Educational Program}

This program is composed of some topics taken from an English grade six book entitled Action Pack 6 (see Appendix 4). The material is prepared as follows:

a- Two units are chosen from the textbook: unit (11) entitled "Has anybody got any question?" and unit (14) entitled "I've never swum in the sea".

b- The rules of present perfect and simple past tenses are selected and analyzed into concepts.

c- Of these concepts, general and specific goals are derived to focus on the students' acquisition of the four skills.

d- The concept of present perfect and simple past tense are developed by using computer and data show.

\subsection{Procedures of Applying Blended Learning Methods}

As stated above, Students of control group are 25. They are in a traditional classroom setting, which is based on a face-to-face session. The students are scheduled to meet their teacher three times a week. Instructional materials manipulated in traditional methods are the textbook, a normal whiteboard, and markers.

On the other side, students of experimental group are also 25 . They are scheduled to meet their teacher three times a week. They are instructed via a blended learning approach in which they have to a face-to-face meeting with the instructor and are taught orally and visually in attempt to interact with the instructor over the content material presented in the classroom. Instructional materials adopted in blended learning are PowerPoint slides, flash cards, computer, data show and resources; they are part of the daily classroom instructions. The students are engaged in online activities, and have an opportunity to demonstrate their knowledge.

\subsection{The Study Sample}

The study sample consists of the sixth-grade students (they are 50 female students) selected from two schools in Amman, namely Alrai school and Alsabelah school. It is selected purposively because of its relevance to the study procedures followed. The sample members are divided into an experimental group including 25 students, and a control group comprising 25 students as indicated in table (1). 
Table 1. The percentage distribution of the two groups in the two schools

\begin{tabular}{llll}
\hline School & Group & Frequency & Percentage \\
\hline Alrai school & Control group & 25 & $50 \%$ \\
Alsabelah school & Experimental group & 25 & $50 \%$ \\
Total & & 50 & $100 \%$ \\
\hline
\end{tabular}

\subsection{Instruments of the Study}

\subsubsection{Achievement Test}

A test is conducted to measure the students' achievement in the English language via the elements of the basic cognitive content distributed according to Blooms'seven categories (knowledge, understanding, comprehension, application, analysis, synthesis and evaluation) (for a fuller account of these categories, see Anderson et al. (2001)) The test questions (they are 12 questions) are set up to cover 20 multiple choice items. Each correct answer is given one 1 mark out of 20 marks (see Appendix A). The students' achievement is estimated by means of the following scale:

1) 0-9 Weak.

2) 10-15 Average.

3) 16-20 Excellent.

\subsubsection{Attitude Questionnaire}

In light of the study questions, the second instrument is applied to survey the attitudes of sixth grade students towards blended learning. The instrument has been designed according to the review of the related studies to show students' attitudes towards the blended learning. It covers 30 items (see Appendix B). Adopting Likert Scale( Allen \& Seaman, 2007), The researchers keep into their consideration that students must choose each item in the questionnaire by virtue of ticking $(\sqrt{ })$ the box they think it is appropriate and each answer has its own score. Scoring is illustrated in table (2):

Table 2. Scores of the students' questionnaire answers

\begin{tabular}{llllll}
\hline Answers & $\begin{array}{l}\text { Strongly } \\
\text { Agree }\end{array}$ & Agree & Neutral & Disagree & $\begin{array}{l}\text { Strongly } \\
\text { Disagree }\end{array}$ \\
\hline Scores & 5 & 4 & 3 & 2 & 1 \\
\hline
\end{tabular}

Attitudes towards English are considered as follows:

1) If the students' attitudes percentage is between $71 \%-100 \%$, this means that they have positive attitudes.

2) If the students' attitudes percentage is between $51 \%-70 \%$, this means that they are average.

3 ) If the students' attitudes percentage is less than $50 \%$, this means that the students' attitudes are negative.

\subsection{The Validity of the Instruments}

The achievement test, teaching materials, and the attitudes questionnaire are introduced to five university professors, and educational supervisors. Modifications are made according to their advice. Members of the jury are attached in (Appendix D).

\subsection{Research Design and Statistical Treatment}

The study contains the following variables:

\section{a- Independent variables:}

1) Blended learning strategy

2) Traditional teaching method.

\section{b- Dependent variables:}

1) Students' achievement in English.

2) Attitudes toward blended learning method.

Moreover, SPSS (Statistical Package of Social Sciences) is manipulated in a way that covariance analysis by (ANCOVA) is carried out to measure both the difference between the means of two groups according to the 
achievement test and the difference between the means of the attitudes of the two groups according to the attitude questionnaire.

\section{Analysis of the Study Results}

It is of great significance to provide a detailed analysis of the data findings in an attempt to answer the questions of the study that have already been raised. As far as the first question is concerned, the means and standard deviations are obtained for the performance of the two study groups (The experimental and the control groups) from the achievement test and its scores as indicated in table (3) below.

Table 3. Means and standard deviations of the two study group's results in achievement test

\begin{tabular}{lllll}
\hline & & Upper & \multicolumn{2}{l}{ Achievement test } \\
\cline { 4 - 5 } The group & Number & end & Mean & Variance \\
\hline Control & 25 & 50 & 3.240 & 1.405 \\
Experimental & 25 & & 4.346667 & 1.191 \\
Total & 50 & & 7.587 & 2.596 \\
\hline
\end{tabular}

Table (3) elucidates that the mean of the experimental group that is taught by using the blending learning is higher than the mean of the other one, since it reaches (4.34), while the mean for the control group that is taught by the traditional method scores (3.24). To determine whether or not there is any significant difference between the means of the study two groups at the level $(\mathrm{a} \leq 0.05)$ in the achievement test, the researchers apply the covariance analysis (ANCOVA) in the coming table.

Table (4) shows that the (F) value regarding the strategy of adopting the blended learning reaches (7.158), with significance level of (0.000). It reflects that there is some sort of differences with statistical significance between the means of the two study groups on the achievement test, and this, in turn, means rejecting the null hypothesis that states: there are no differences with statistical significance at the level $(a \leq 0.05)$ in the sixth grade students' achievement when learning the English language.

Table 4. Results of (ANCOVA) analysis of the difference between the means of the two study groups on the achievement test

\begin{tabular}{|c|c|c|c|c|c|c|}
\hline Source & Type III Sum of Squares & Df & $\begin{array}{l}\text { Mean } \\
\text { Square }\end{array}$ & $\mathrm{F}$ & Sig. & $\begin{array}{l}\text { Partial Eta } \\
\text { Squared }\end{array}$ \\
\hline Corrected & 6.928 & 2 & 3.464 & 6.435 & 003 & 215 \\
\hline \multicolumn{7}{|c|}{ Model Intercept } \\
\hline Test & 102.709 & 1 & 102.709 & 190.781 & 000 & 802 \\
\hline Error & 3.853 & 1 & 3.853 & 7.158 & 010 & 132 \\
\hline \multirow[t]{2}{*}{ Corrected } & 25.303 & 47 & 538 & & & \\
\hline & 752.105 & 49 & & & & \\
\hline
\end{tabular}

In relation to answering the second question already posed before, Table (5) demonstrates that the means of the experimental group that is taught by using the blended learning is higher, since it reaches (4.33), while the means of the control group that is given traditional-method courses scores (3.24).

Table 5. The means and standard deviations of the performance of the two study groups on the attitudes questionnaire

\begin{tabular}{lllll}
\hline The group & Number & \multirow{2}{*}{$\begin{array}{l}\text { Upper } \\
\text { end }\end{array}$} & & \multicolumn{2}{l}{ Achievement test } \\
\cline { 4 - 5 } & & Mean & Variance \\
\hline Control & 25 & 50 & 3.24 & 1.24 \\
Experimental & 25 & & 4.33 & 1.87 \\
Total & 50 & & 7.57 & 3.10 \\
\hline
\end{tabular}

To determine if the differences between the means of the two study groups are with statistical significance at level $(a \leq 0.05)$, the researchers have applied (ANCOVA) as shown in table (6): 
Table 6. Results of (ANCOVA) analysis of the difference between the means of the attitudes of the two study groups on the attitudes questionnaire

\begin{tabular}{lllllll}
\hline Source & Type III Sum of Squares & DF & Mean Square & F & Sig. & Partial Eta Squared \\
\hline $\begin{array}{l}\text { Corrected } \\
\text { Model }\end{array}$ & 44.287 & 2 & 22.143 & 8.412 & 0.001 & 0.264 \\
Intercept & 6.282 & & & & & \\
Test & 18.087 & 1 & 6.282 & 2.386 & 0.129 & 0.048 \\
Error & 123.713 & 1 & 18.087 & 6.872 & 0.012 & 0.128 \\
Corrected & 168.000 & 47 & & & & \\
\hline
\end{tabular}

As indicated by the above table, the $(\mathrm{F})$ value for the strategy scores (6.872) with significance level $(\mathrm{a} \leq 0.05)$, which reflects the presence of statistical significant differences between the means of the performance of the two study groups on the attitudes questionnaire, and this means there is a growing tendency to reject the second null hypothesis that states: there are no differences with statistical significance at the level $(a \leq 0.05)$ in terms of the sixth grade students' attitudes towards making use teaching strategy of the blended learning, and the traditional method.

\section{General Discussion of the Study Findings}

In the light of the findings, the current study reveals that a line of demarcation of statistical significance can obviously be drawn between the means of the results of the two groups on the achievement test, whereby the difference is in favor of the experimental group that is given courses by using the strategy of blended learning. It is not doubted to state that blended learning represents an effective method in teaching English, and it positively reflects the student s' performance in dealing with a specific subject: the experimental group is able to visualize the learning materials by displaying them on Power Point presentations and via Internet sites. This leads to create a link between the theoretical side and the practical side, which, by itself, facilitates the learning process and acceptance in general.

This recent strategy has had an unrivaled reputation because of employing both the e-learning and traditional learning in a blend, and consequently the students' achievement in English and their linguistic skills improve considerably. The very use of blended learning strategy plays a vital role in turning the educational environment to a creative and interactive learning setting. It also opens new horizons to shift the educational process from a teacher-centered class to a student-centered class. This, in a way or another, contributes to developing the quality of the teaching-learning process, improving its outputs, opening new potentials for self-learning as well as for long life learning, and raising students' achievement level in English. Moreover, it improves students' skills, including communication skills, and information perception. It reinforces the interaction between the student and the teacher. In short, the experimental group receives systematic and strategic learning.

On the other hand, the results also unveil that there is a greater divergence of statistical significance between the means of the two group's performance on the attitudes measure. The divergence, once again, is in favor of the experimental group that is taught by using the blended learning strategy. The exploitation of the blended learning strategy has the effect on the attitudes of the sixth grade students compared to those who are taught by the traditional method. It is possible to justify so by a set of factors, among which the most important one is that blended learning provides the experimental group with the opportunity to learn freely. It also equips them with a positive atmosphere to the extent that it creates an effective environment for the development of communication. In addition, via the learning process, students would have a broad experience of using various electronic media multi-throwing lessons in the classroom, receiving information, interacting and communicating with their teachers. Blended learning that is based on the interaction between teachers and students and on freedom of learning enables the experimental group students to participate and answer questions without hesitancy, and to strengthen their feeling of self- confidence and pride of themselves.

In conclusion, an analysis of the overall results of the study indicates that blended learning represents a highly effective method in teaching English, and above all, to a great extent, reflects positively the students' performance in dealing with learning materials in general. The vital role blended learning strategy plays is resulted from how students look seriously at this method, and how they express their own satisfaction with this newly adopted strategy simply because they are a major part of a learning process. Moreover, employing blended learning strategy as a teaching method contributes very much to enhancing students' learning competence as well as their performance in English. It also develops students' different skills, including communication skills, receiving information and their interaction with teachers. 


\section{References}

Allen, E., \& Seaman, C. (2007). Likert Scales and Data Analyses. Quality Progress (pp. 64-65).

Anderson, L. W., Krathwohl, D. R., Airasian, P. W., Cruikshank, K. A., Mayer, R. E., Pintrich, P. R., ... Wittrock, M. C. (2001). A Taxonomy for Learning, Teaching, and Assessing: A revision of Bloom's Taxonomy of Educational Objectives. New York: Pearson, Allyn \& Bacon.

Bersin \& Associates. (2003). Blending Learning: What Work? An Industry Study of the Strategy, Implementation, and Impact of Blended Learning. Oakland CA: Bersin \& Associates.

Driscoll, M. (2002). Blended Learning: Let's Get beyond the Hype. LTI News line: Learning \& Training Innovation. Retrieved from http//www-07.ibm.com/Services/pdf/blended_learning.pdf

Graham, C. R. (2006). Blended Learning Systems: Definition, Current Trends, and Future Directions. In C. J. Bonk \& C. R. Graham (Eds.), The Handbook of Blended Learning: Global Perspectives (pp. 1-4). San Francisco: Pfeiffer.

Morgan, K. R. (2002). Blended learning: A Strategic Action Plan for a New Campus. Florida: University of Central Florida.

Penn, J., Mackay, B., \& Harmes, S. (2014). Action Pack 6. London: York Press.

Smythe, M. (2011). Blended learning: A transformative process? New Zealand: Nelson Marlborough Institute of Technology.

Thorne, K. (2003). Blended learning: How to Integrate Online and Traditional Learning. London: Longman.

Valiathan, P. (2002). Blended Learning Models. Learning Circuits. Retrieved from www.learningcircuits.org/2002/aug2002/valiathan.htm

Wilson, J. W. (2013). 6 Models of Blended Learning. Retrieved from https://doi.org/10.1108/jeit.2000.00324eab.009

\section{Appendix A}

\section{Achievement Test}

\section{Answer all the Ouestions in the right place}

Read and match the definition with the suitable word.

1. Brave

2. Author

3. Break

4. Coach a) Ready to face danger.

b) Separate into pieces.

c) A trainer.

d) A book writer.

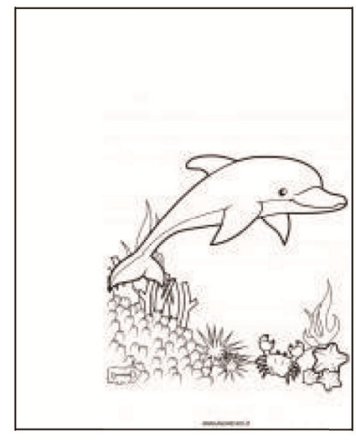

\section{Write the Synonymous for these words.}

1. Modern:

2. Basket:

3. Painful:

4. Helpful:

Choose the correct verb to complete these sentences:

1. Do you the newspaper every day? If so, which one?

a- read b- reading c-reads d-is reading

2. When I to this country, the only work I could find was as a night security guard.

a- come b-came c-coming d- comes

3. Next month, I start degree in literature by distance learning.

a- am going to b-is going to c-are going to d-going to

Choose the correct word or phrase to complete these sentences: 
4- Keep the on your ankle for six weeks.
a. Painful
b. Plaster
c. Climber.
d. Present

5- Look and choose.

a. I've always wanted to spend a night in a castle.

b. I've always wanted to swim with dolphins.

c. I've always wanted to travel the world.

d. I've always wanted to climb a mountain.

6- Look and choose

a. I've always wanted to meet a famous author.

b. I've always wanted to spend a night in a castle.

c. I've always wanted to travel the world.

d. I've always wanted to climb a mountain.

7- Write the sentences correctly (no I've never won competition)

a. No I've never won competition.

b. No I've ever won competition.

c. No I've ever won competition!

d. No I've ever won competition?

8-Has your father. Travelled to Italy?
a. Ever.
b. Never.
c. Always.
d. will.

9. Write the sentences correctly (have you ever flown in a plane)
a. Have You ever flown in a plane?
b. Have you ever flown in a plane?
c. Have you ever flown in a plane?
d. Have you ever flown in a plane?
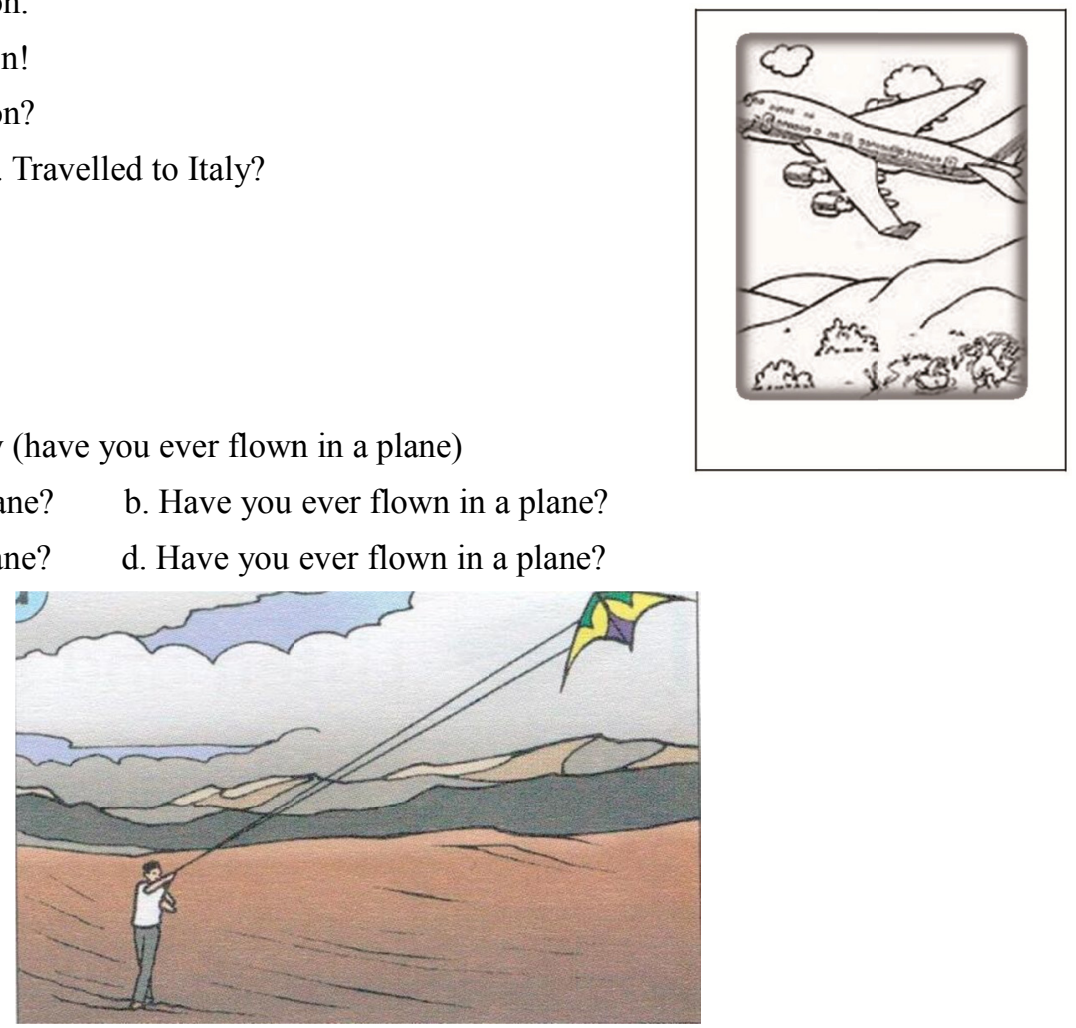

10- Look at the picture and choose.

a- The visitors' centre at Wadi Rum is big and modern. Tourists can find everything there like map, postcards, information, and a restaurant. And a craft shop. I got a map for our visit and we ate in the restaurant. After that we went to the craft shop, and bought some postcards.

b- Everybody meets the jeep guides in front of the visitors' center. They know everything about wadi rum.

c- After that, we went to the Barrage canyon.

d- We were at wadi rum all day. We did lots of climbing. We also watched some professional kite-flying. Everybody felt tired, but we didn't want to go home. 


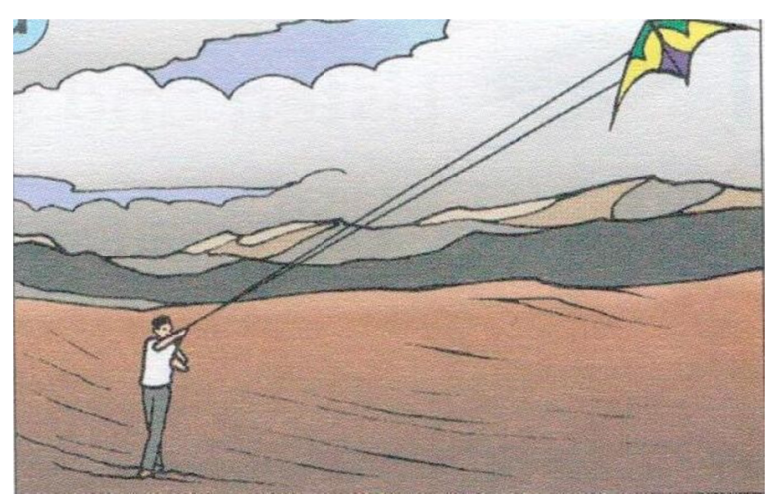

11 - Look at the picture and choose.

a-We were at wadi rum all day. We did lots of climbing. We also watched some professional kite-flying. Everybody felt tired, but we didn't want to go home.

b- After that, we went to the Barragh canyon.

c- Everybody meets the jeep guides in front of the visitors' center. They know everything about wadi rum. Our guides were very friendly and helpful.

d- The visitors centre at Wadi Rum is big and modern. Tourists can find everything there like map, postcards, information, and a restaurant. And a craft shop. I got a map for our visit and we ate in the restaurant. After that we went to the craft shop, and bought some postcards.

\section{2- Look at the picture and choose.}

a-Everybody meets the jeep guides in front of the visitors' center. They

know everything about wadi rum. Our guides were very friendly and helpful.

b- The visitors centre at Wadi Rum is big and modern. Tourists can find everything there like map, postcards, information, and a restaurant. And a craft shop. I got a map for our visit and we ate in the restaurant. After that we went to the craft shop, and bought some postcards.

c- We were at wadi rum all day. We did lots of climbing. We also watched some professional kite-flying. Everybody felt tired, but we didn't want to go home.

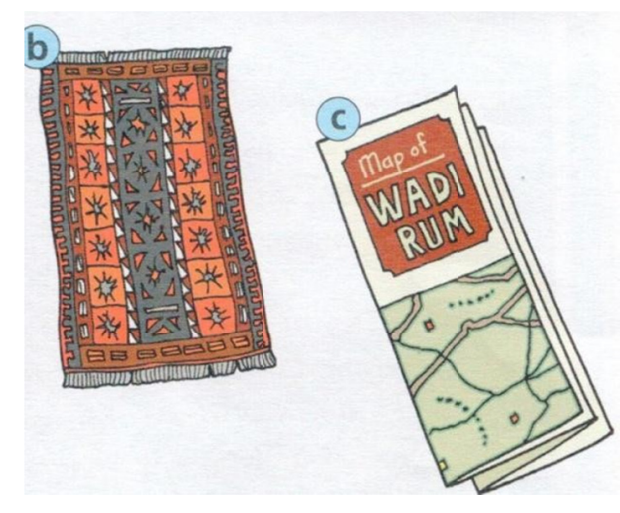

d- After that, we went to the Barragh canyon.

\section{Appendix B}

Attitudes Questionnaire (Translated)

\section{Blended Learning}

Dear Students:

This questionnaire aims at exploring your opinion regarding the use of blended learning in teaching English: advantages, limitations and suggestions for improvement. You are kindly requested to fill out this questionnaire. Your objective and truthful answers will help us get a realistic assessment of this experience. 


\begin{tabular}{|c|c|c|c|c|c|c|}
\hline No. & Item & $\begin{array}{l}\text { Strongly } \\
\text { Agree }\end{array}$ & Agree & Neutral & $\begin{array}{l}\text { Don't } \\
\text { agree }\end{array}$ & $\begin{array}{l}\text { Strongly } \\
\text { don't agree }\end{array}$ \\
\hline 1 & I have easy access to a computer terminal in my school. & & & & & \\
\hline 2 & I am experienced in accessing information from the web. & & & & & \\
\hline 3 & $\begin{array}{l}\text { Blended learning helps learners carry out their academic tasks more } \\
\text { efficiently. }\end{array}$ & & & & & \\
\hline 4 & $\begin{array}{l}\text { Blended learning may enhance my status among my friends in the } \\
\text { local community. }\end{array}$ & & & & & \\
\hline 5 & $\begin{array}{l}\text { Blended learning courses are more motivated to learners than } \\
\text { traditional ones. }\end{array}$ & & & & & \\
\hline 6 & $\begin{array}{l}\text { Blended learning encourages learners to assume responsibility for } \\
\text { their own learning. }\end{array}$ & & & & & \\
\hline 7 & Blended learning helps learners become self- knowledgeable. & & & & & \\
\hline 8 & Blended learning helps learners feel self-confidence. & & & & & \\
\hline 9 & $\begin{array}{l}\text { Blended learning helps learners support further their education in } \\
\text { the future. }\end{array}$ & & & & & \\
\hline 10 & $\begin{array}{l}\text { I prefer blended learning activities offered via electronic meetings } \\
\text { since they pose questions that need a high degree of thinking. }\end{array}$ & & & & & \\
\hline 11 & $\begin{array}{l}\text { Carrying out the required electronic activities bores learners too } \\
\text { much. }\end{array}$ & & & & & \\
\hline 12 & $\begin{array}{l}\text { Due to the long time of preparation and great effort that blended } \\
\text { learning requires, it leads to some sort of dissatisfactory feelings. }\end{array}$ & & & & & \\
\hline 13 & $\begin{array}{l}\text { I prefer attending virtual class meetings more than attending } \\
\text { face-to- face meetings. }\end{array}$ & & & & & \\
\hline 14 & $\begin{array}{l}\text { The services that the school provides in relation to blended learning } \\
\text { are are satisfactory. }\end{array}$ & & & & & \\
\hline 15 & $\begin{array}{l}\text { I am satisfied with the activities which required to do in blended } \\
\text { learning environment. }\end{array}$ & & & & & \\
\hline 16 & $\begin{array}{l}\text { Blended learning offers the possibilities to efficiently manage the } \\
\text { time. }\end{array}$ & & & & & \\
\hline 17 & Blended learning is not efficient as a learning style. & & & & & \\
\hline 18 & Deadlines in blended learning activities cause me to fail. & & & & & \\
\hline 19 & $\begin{array}{l}\text { I am satisfied with the way of distribution scores to the different } \\
\text { activities (assignments, quizzes, exams etc). }\end{array}$ & & & & & \\
\hline 20 & Blended learning encourages learners pursue through information. & & & & & \\
\hline 21 & $\begin{array}{l}\text { I get more information in the area of my study via blended learning } \\
\text { than through traditional courses. }\end{array}$ & & & & & \\
\hline 22 & I feel happy when I take a course via blended learning. & & & & & \\
\hline 23 & $\begin{array}{l}\text { I enjoy modern tools and equipments such as (computer, } \\
\text { internet...etc.) required by blended learning. }\end{array}$ & & & & & \\
\hline 24 & A blended learning session keeps me always open-minded. & & & & & \\
\hline 25 & $\begin{array}{l}\text { Interaction is adequately maintained with the teacher when he/she } \\
\text { is running the blended learning classroom. }\end{array}$ & & & & & \\
\hline 26 & $\begin{array}{l}\text { Blended learning is considered to be a collective activity } \\
\text { rather than an individual one. }\end{array}$ & & & & & \\
\hline 27 & $\begin{array}{l}\text { I am satisfied with my participation in the class, because of the new } \\
\text { method. }\end{array}$ & & & & & \\
\hline 28 & $\begin{array}{l}\text { I am satisfied with the quality of interaction between all involved } \\
\text { parties (Technology, Teachers, and Students). }\end{array}$ & & & & & \\
\hline 29 & $\begin{array}{l}\text { I am dissatisfied with the process of collaboration activities during } \\
\text { the course. }\end{array}$ & & & & & \\
\hline 30 & I am satisfied with the way I interact with other students. & & & & & \\
\hline
\end{tabular}




\section{Appendix C}

\section{Plan Units (11-14)}

Subject: Action Pack 6

Number of Classes: 6

\section{Semester: 2nd semester}

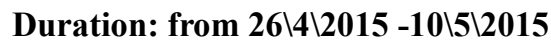

\begin{tabular}{|c|c|c|c|c|c|}
\hline \multirow[t]{2}{*}{ Outcomes } & \multirow{2}{*}{$\begin{array}{l}\text { Resources } \\
\text { and Assessment Material }\end{array}$} & \multirow{2}{*}{$\begin{array}{l}\text { Instructional } \\
\text { Strategies }\end{array}$} & \multicolumn{2}{|l|}{ Assessment } & \multirow{2}{*}{$\begin{array}{l}\text { Associated } \\
\text { Activities }\end{array}$} \\
\hline & & & Strategy & Tool & \\
\hline $\begin{array}{l}\text { To use present perfect with frequency } \\
\text { adverb never and always }\end{array}$ & student book & Lecture & Presentation & $\begin{array}{l}\text { Rating } \\
\text { Scale }\end{array}$ & $\begin{array}{l}\text { Pupils should count } \\
\text { correctly }\end{array}$ \\
\hline $\begin{array}{l}\text { To follow oral } \\
\text { instructions }\end{array}$ & Chalk Board & Presentation & $\begin{array}{l}\text { Simulation/ } \\
\text { Role playing }\end{array}$ & Rubric & $\begin{array}{l}\text { To sign to } \\
\text { materials and say it } \\
\text { correctly }\end{array}$ \\
\hline To use future tense & Student book & Lecture & Presentation & $\begin{array}{l}\text { Rating } \\
\text { Scale }\end{array}$ & $\begin{array}{l}\text { Pupils should count } \\
\text { correctly }\end{array}$ \\
\hline $\begin{array}{l}\text { To use present perfect } \\
\text { with frequency adverb never and always }\end{array}$ & Flash Cards & & & & \\
\hline $\begin{array}{l}\text { To use correctly } \\
\text { learning vocabulary }\end{array}$ & Power Point & $\begin{array}{l}\text { Project- } \\
\text { based learning }\end{array}$ & $\begin{array}{l}\text { Random } \\
\text { observation }\end{array}$ & $\begin{array}{l}\text { Chick } \\
\text { List }\end{array}$ & $\begin{array}{l}\text { To draw cars } \\
\text { and count them }\end{array}$ \\
\hline \multicolumn{6}{|l|}{$\begin{array}{l}\text { To use past tense with the conjunction } \\
\text { "when" }\end{array}$} \\
\hline $\begin{array}{l}\text { To ask and answer } \\
\text { questions using the past }\end{array}$ & Student book & & & & \\
\hline $\begin{array}{l}\text { To spell correctly } \\
\text { learning Vocabulary }\end{array}$ & Computer & $\begin{array}{l}\text { Project } \\
\text { based learning }\end{array}$ & $\begin{array}{l}\text { Student - } \\
\text { portfolio }\end{array}$ & Rubric & $\begin{array}{l}\text { To have } \\
\text { different drawings and } \\
\text { color them }\end{array}$ \\
\hline $\begin{array}{l}\text { To pronounce English } \\
\text { words and sentences precisely and } \\
\text { correctly }\end{array}$ & Data show & & & & \\
\hline $\begin{array}{l}\text { To use the present } \\
\text { perfect to talked action up to now }\end{array}$ & Notebook & & & & \\
\hline \multicolumn{6}{|l|}{$\begin{array}{l}\text { To listen for specific } \\
\text { information }\end{array}$} \\
\hline \multicolumn{6}{|l|}{$\begin{array}{l}\text { To use words and } \\
\text { simple sentences to take part in simple } \\
\text { Exchanges }\end{array}$} \\
\hline \multicolumn{6}{|l|}{$\begin{array}{l}\text { To listen to and sing } \\
\text { along with a song }\end{array}$} \\
\hline \multicolumn{6}{|l|}{$\begin{array}{l}\text { To ask and answer } \\
\text { questions using the present perfect }\end{array}$} \\
\hline \multicolumn{6}{|l|}{$\begin{array}{l}\text { To demonstrate } \\
\text { understanding of simple information } \\
\text { learning materials }\end{array}$} \\
\hline \multicolumn{6}{|l|}{$\begin{array}{l}\text { To write sentences } \\
\text { and simple paragraphs on familiar topics } \\
\text { for specific purposes }\end{array}$} \\
\hline \multicolumn{6}{|l|}{ To read a story } \\
\hline To read for summary & & & & & \\
\hline
\end{tabular}




\section{Appendix D}

\section{The Slides that Show the Studying Subjects}
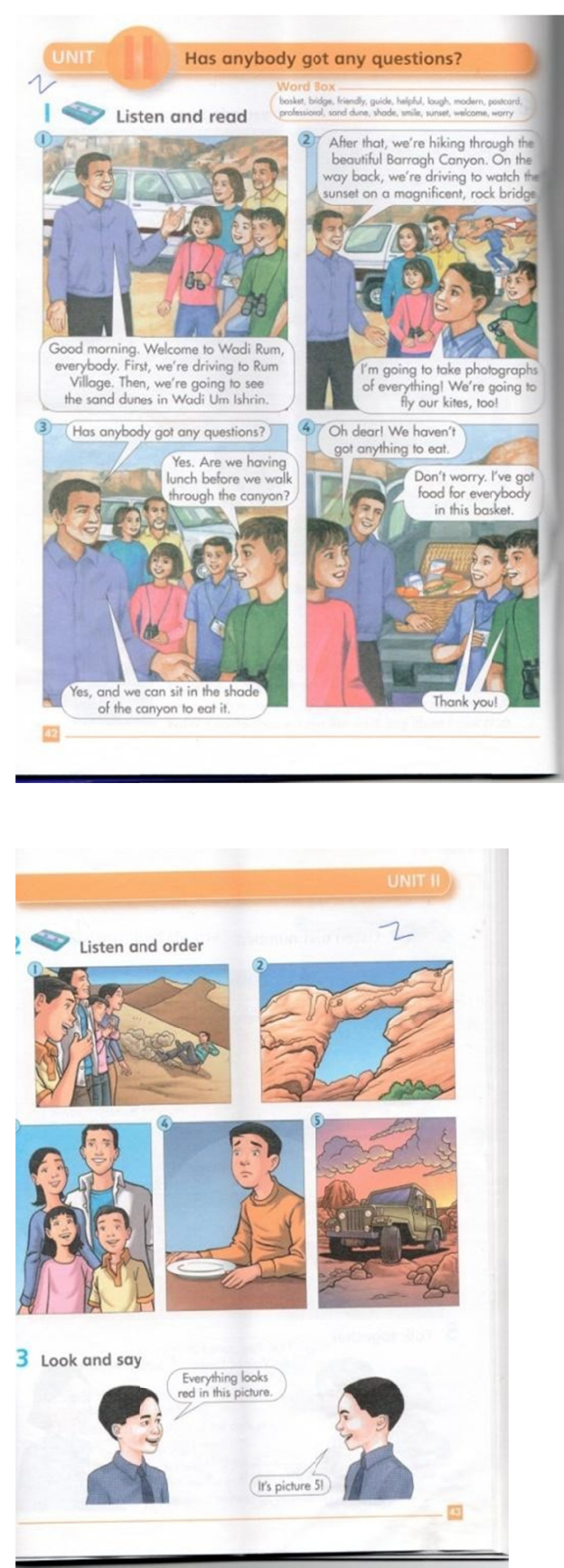
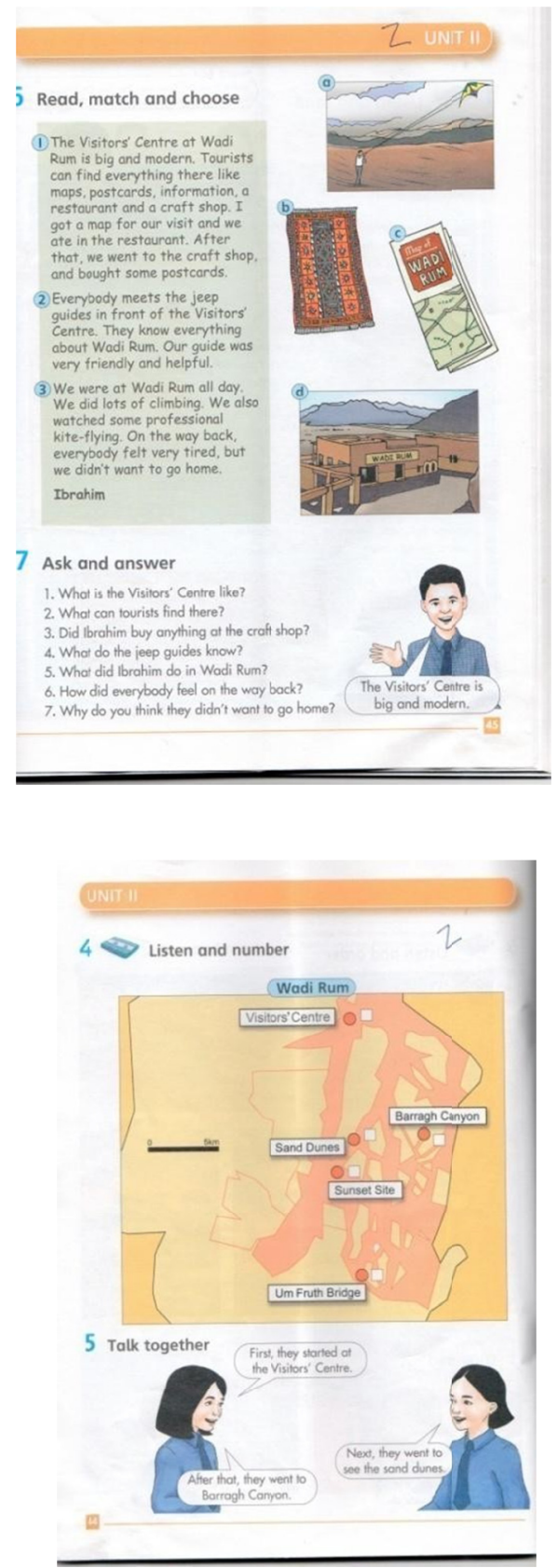

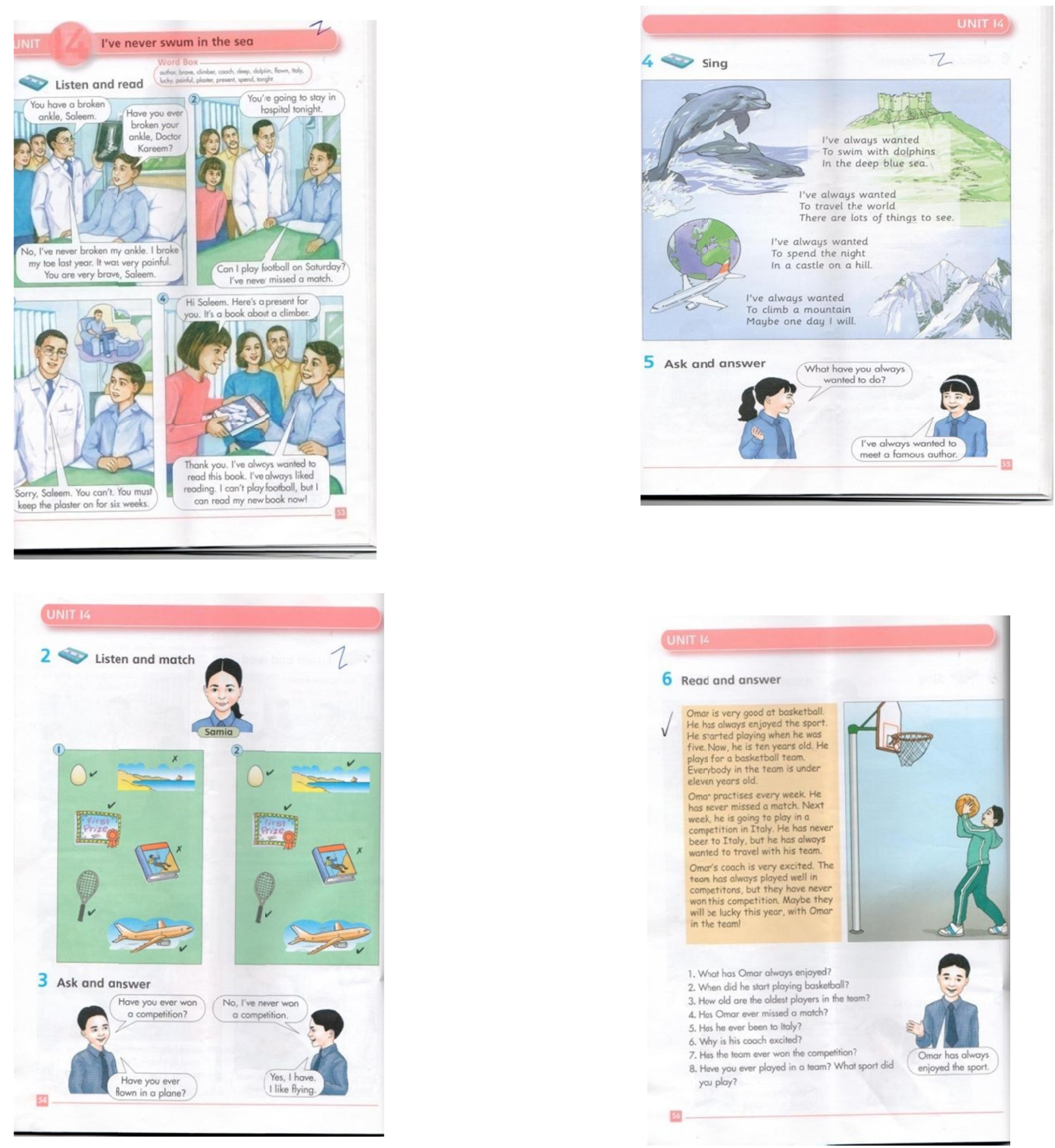

\section{Appendix E}

\section{Panel of Experts}

\begin{tabular}{llll}
\hline $\mathbf{N}$ & Name & Rank & Place of work \\
\hline 1 & Abd AL Jabar AL Byatee & Professor & MEU \\
2 & Abbas Abd Mahadi AL Sharefe & Professor & MEU \\
3 & Nurma AL Zayed & Assistant Professor & MEU \\
4 & Rema Mahmood & Assistant Professor & AL-Albayt University \\
\hline
\end{tabular}

\section{Copyrights}

Copyright for this article is retained by the author(s), with first publication rights granted to the journal.

This is an open-access article distributed under the terms and conditions of the Creative Commons Attribution license (http://creativecommons.org/licenses/by/4.0/). 